Türkiye Tarımsal Araştırmalar Dergisi
dergipark.gov.tr/tutad $\begin{aligned} & \text { Turk J Agric Res } \\ & \text { 2017, 4(1): 43-49 } \\ & \text { O TÜTAD } \\ & \text { ISSN: 2148-2306 } \\ & \text { e-ISSN: 2528-858X } \\ & \text { doi: 10.19159/tutad.300616 }\end{aligned}$

\title{
Bazı Tritikale ( $X$ Triticosecale Wittmack) Genotiplerinin Verim ve Kalite Özelliklerinin Belirlenmesi
}

\author{
Ferhat KIZILGEÇi ${ }^{* *}$, Mehmet YILDIRIM ${ }^{2}$ \\ ${ }^{1}$ Şirnak Üniversitesi, Ziraat Fakültesi, Tarla Bitkileri Bölümü, Şırnak, TÜRKIYE \\ ${ }^{2}$ Dicle Üniversitesi, Ziraat Fakültesi, Tarla Bitkileri Bölümü, Diyarbakır, TÜRKIYE
}

\begin{abstract}
Geliş Tarihi/Received: 20.08.2016
Kabul Tarihi/Accepted: 03.01.2017

*Sorumlu Yazar/Corresponding author: ferhat_kizilgeci@hotmail.com

Özet: Bu araştırma; 2014-2015 yetiştirme döneminde, 9 tritikale genotipi (41-ITSN-8022, 41-ITSN-8023, 41-ITSN-8024, 41-ITSN-8036, 41-ITSN-8053, 41-ITSN-8061, DZ9-01-01, DZ9-01-02 ve DZ9-06)'nin Diyarbakır ve Mardin lokasyonlarında verim ve kalite ile ilgili bazı özellikleri incelenerek, bölgeye adaptasyonlarının belirlenmesi amacıyla yürütülmüștür. Çalışmada ayrıca, 2 ekmeklik buğday çeșidi (Pehlivan ve Cemre) de standart olarak kullanılmıștır. Araştırma, tesadüf blokları deneme desenine göre 4 tekerrürlü olarak yürütülmüştür. Çalışmada tane verimi, bin tane ağırlığı, hektolitre ağırlığı, protein içeriği, nişasta içeriği, gluten (yaş öz) içeriği ve zeleny sedimantasyon özellikleri incelenmiştir. Araştırma bulgularına göre lokasyonlar arası farklılıklar protein içeriği hariç, diğer tüm özellikler için önemli bulunmuştur. Araştırmada ele alınan genotiplere ait tane verimi $537.5-678.5 \mathrm{~kg} \mathrm{da}^{-1}$, bin tane ağırlığı $29.84-45.21 \mathrm{~g}$, hektolitre ağırlığı 73.13-79.50 $\mathrm{kg} \mathrm{hL}^{-1}$, protein oranı \% 14.00-16.19, nişasta içeriği \% 62.48-64.65, gluten içeriği \% 30.5334.53 ve zeleny sedimantasyon değeri $48.67-55.36 \mathrm{~mL}$ arasında değişim göstermiştir. Araştırma sonuçlarına göre, incelen özellikler yönünden DZ9-06 hattının çeşit adayı olarak değerlendirilebileceği sonucuna varılmıştır.
\end{abstract}

Anahtar Kelimeler: Tritikale, çevre, tane verimi, protein içeriği, zeleny sedimentasyon

\section{Determination of Yield and Quality Components of Some Triticale (X Triticosecale Wittmack) Genotypes}

\begin{abstract}
This research was carried out to determine local adaptations of 9 triticale genotypes (41-ITSN-8022, 41-ITSN8023, 41-ITSN-8024, 41-ITSN-8036, 41-ITSN-8053, 41-ITSN-8061, DZ9-01-01, DZ9-01-02 and DZ9-06) by examining some traits related to grain yield and quality components during 2014-2015 growing season in Diyarbakır and Mardin locations. Two bread wheat cultivars (Pehlivan and Cemre) were used as check cultivar. Study was conducted according to Randomized Complete Block Design with four replications. The traits of grain yield, thousand kernel weight, test weight, protein content, starch content, wet gluten content and zeleny sedimantation were investigated. According to the findings of research, differences between locations were found significant for all investigated traits except protein content. The values ranged in genotypes were between 537.5-678.5 $\mathrm{kg} \mathrm{da}^{-1}$ in grain yield, 29.89-45.21 $\mathrm{g}$ in thousand kernel weight, 73.13-79.50 $\mathrm{kg} \mathrm{hL}^{-1}$ test weight, $14.00-16.19 \%$ in protein content, $62.48-64.65 \%$ in starch content, $30.53-34.53 \%$ in wet glutein content and $48.67-55.36 \mathrm{~mL}$ in zeleny sedimantation. DZ9-06 line was determined promising as a new cultivars candidate.
\end{abstract}

Keywords: Triticale, environment, grain yield, protein content, zeleny sedimantation

\section{Giriș}

Dünyada ve ülkemizde insanların temel besin ihtiyacını karşılama açısında tahıllar önemli bir yere sahiptir. Tahıllar içerisinde özellikle serin iklim tahılları beslenme alışkanlığımız içerisinde önemli bir yer edinmektedir. Dünya nüfusunun sürekli artışı, besin açığını da beraberinde getirmektedir. $\mathrm{Bu}$ nedenle insanların besin ihtiyaçlarını karşılayacak gıda üretimi için güvenli 
ve verimli alanlar yanında marjinal alanlarda da üretim yapmak zorunluluğu bulunmaktadır (Bağc1 ve Ekiz, 1993). Bilim insanlarının son yıllardaki çabaları bu soruna çözüm bulmaya yönelik olmaktadır. Bu amaçla ilk türler arası melez kültür bitkisi olan Tritikale (X Triticosecale Wittmack), çavdarın olumsuz çevre koşullarına olan direnci ile buğdayın verim ve kalite potansiyeline sahip bir serin iklim tahıl bitkisidir. Ülkemizde tritikale bitkisi; 372.063 dekar alanda, 125 bin ton üretimi yapılmaktadır (Anonim, 2016). Güneydoğu Anadolu Bölgesi'nde ise 3.336 dekar alanda 986 ton üretimle bölgeler arasında son siralarda yer almaktadır (Anonim, 2016).

Tritikale 1slahını ilk yıllarında tritikale ekiminin yayılmasını sınırlayan en önemli faktörlerden biri diğer tahıllara göre ekmek yapımı kalitesinin daha düşük olmasıdır. Ekmeklik kalitesinin düşük olmasının nedeni düşük gluten kalitesi ve yüksek miktardaki alfa amilaz aktivitesi tritikalenin ekmeklik kalitesini düşürmektedir. Yeni 1slah edilen tritikale çeşitlerinin kalite özelliklerinin iyileştirilmesi sonucunda un ve yem sanayide kullanılmaya başlanmıştır. Tritikalenin kıraç koşullarda özellikle çiçeklenme başlangıcı ile tane doldurma döneminde yağışın yetersiz olduğu yıllarda buğdaydan daha yüksek verime sahip ve verimin daha stabil olduğu saptanmıştır (Genç ve ark., 1987; Yağbasanlar, 1987). Ülkemizde yapılan birçok araştırmanın ortaya koyduğu gibi, tritikale verim potansiyelinin buğdaya yaklaşması, buğday veriminin düşük olduğu yüksek rakımlı, asitli ve hastalık probleminin olduğu yerlerde ticari amaçlı tritikale tarımına olanak sağlamaktadır. $\mathrm{Bu}$ çalışmada; bazı tritikale genotiplerinin farklı bölgelerde verim ve kalite özellikleri incelenerek, yüksek performanslı genotip veya genotiplerin belirlenmesi amaçlanmıştır.

\section{Materyal ve Yöntem}

Bu araştırma; 2014-2015 yetiştirme döneminde, Dicle Üniversitesi Ziraat Fakültesi deneme arazisi ve Mardin ili Derik ilçesi koşullarında yürütülmüştür. Araştırmada; 9 ileri kademe tritikale genotipi (ICARDA kaynakl 6 hat ve Dicle Üniversitesi Ziraat Fakültesi tarafindan geliştirilen 3 hat) ve standart materyal olarak 2 ekmeklik buğday çeşidi (Pehlivan ve Cemre) deneme materyali olarak kullanılmıştır.
Her iki lokasyondan ekim öncesi 0-30 cm derinliğinden alınan toprak örneklerinin analiz sonuçları Tablo 1'de verilmiştir. Tablo 1'den görüleceği üzere, her iki deneme alanı topraklarının; killi-tınlı bünyeli olduğu, toprak pH'sının hafif alkalin karakterli ve tuzluluk probleminin olmadığ 1 ; organik madde miktarı ve alınabilir fosfor (P) bakımından çok az, alınabilir potasyum (K) kapsamı bakımından çok yüksek ve kireç bakımından ise orta kireçli düzeyde olduğu belirlenmiştir.

İklim verileri incelendiğinde; Ekim-Haziran ayları arası toplam yağış miktarı Mardin lokasyonunda $692.8 \mathrm{~mm}$, Diyarbakır lokasyonunda $556.2 \mathrm{~mm}$ olarak gerçekleşmiştir. Çalışmanın yürütüldüğü 2015 yılında Diyarbakır lokasyonuna düşen yağış miktarı uzun yıllar ortalamasına göre daha düşük olmuştur. Sicaklık ortalamaları her iki lokasyonda uzun ortalaması benzerlik göstermiştir (Tablo 2).

Araştırmada denemeler, tesadüf blokları deneme desenine göre 4 tekrarlamalı olarak kurulmuş olup; ekim, metrekareye 400 tohum gelecek şekilde, 6 sıralı parsel ekim mibzeri ile 4.8 $\mathrm{m}^{2}(1.2 \mathrm{~m} \times 4 \mathrm{~m})$ parsel alanına Kasım ayı içerisinde yapılmıştır. Ekim öncesi toprak analiz sonuçlarına göre; her iki lokasyonda da, ekimle birlikte dekara $6 \mathrm{~kg} \mathrm{da}^{-1}$ saf azot $(\mathrm{N})$ ve $6 \mathrm{~kg} \mathrm{da}^{-1}$ saf fosfor $\left(\mathrm{P}_{2} \mathrm{O}_{5}\right)$ gelecek şekilde hesaplanarak 2020-0 (N-P-K) kompoze gübre ile gübreleme yapılmıştır. Bitkilerin kardeşlenme-sapa kalkma döneminde ise üst gübre olarak, $6 \mathrm{~kg} \mathrm{da}^{-1}$ saf $\mathrm{N}$ hesabı ile \% $33 \mathrm{~N}$ içeren amonyum nitrat gübresi ile verilmiştir.

Tane verimi: Parsel biçerdöveri ile yapılan hasat harman işlemi sonucunda elde edilen tritikale taneleri tartılmış ve parsel alanı dikkate alınarak dekara tane verimi $(\mathrm{kg})$ tespit edilmiştir.

Protein içeriği, nişasta içeriği, gluten (yaş öz) içeriği, hektolitre ăgırlı̆̆l ve zeleny sedimantasyon: $\mathrm{Bu}$ özellikler taneler ögütme işlemine tabi tutulmadan NIT SystemInfratec 1241 Grain Analyzer (Foss, Hillerod, Danimarka) cihazıyla ölçülerek belirlenmiştir (Osborne, 2006).

Bin tane ăgırlı̆̆l: Tane sayma makinesi ile sayılan 4 adet 100 'er tohum tartılarak ortalamaları alınmış ve 10 ile çarpılarak bin tane ağırlı̆̆ belirlenmiştir.

Tablo 1. Araştırma topraklarının bazı fiziksel ve kimyasal özelliklerine ait analiz sonuçları

\begin{tabular}{lcccccccc}
\hline Lokasyon & $\begin{array}{c}\text { Saturasyon } \\
(\%)\end{array}$ & $\begin{array}{c}\text { Bünye } \\
\text { sinıfı }\end{array}$ & $\mathrm{pH}$ & $\begin{array}{c}\mathrm{EC} \\
\left(\mathrm{ds} \mathrm{m}^{-1}\right)\end{array}$ & $\begin{array}{c}\text { Kirec } \\
\left(\mathrm{CaCO}_{3}\right) \\
(\%)\end{array}$ & $\begin{array}{c}\text { Organik } \\
\text { madde } \\
(\%)\end{array}$ & $\begin{array}{c}\mathrm{P}_{2} \mathrm{O}_{5} \\
\left(\mathrm{~kg} \mathrm{da}^{-1}\right)\end{array}$ & $\begin{array}{c}\mathrm{K}_{2} \mathrm{O} \\
\left(\mathrm{kg} \mathrm{da}^{-1}\right)\end{array}$ \\
\hline Diyarbakır & 66 & Killi-tınl1 & 7.5 & 0.114 & 10.04 & 0.63 & 2.00 & 144 \\
Mardin & 65 & Killi-tınl1 & 7.8 & 0.128 & 11.02 & 0.81 & 1.26 & 166 \\
\hline
\end{tabular}


Tablo 2. Araştırmanın yürütüldüğü lokasyonlara ait uzun yıllar (1950-2015) ve araştırma yılları bazı iklim verileri

\begin{tabular}{|c|c|c|c|c|c|c|}
\hline \multirow{2}{*}{ Aylar } & \multirow{2}{*}{ Lokasyon } & \multicolumn{2}{|c|}{ Ortalama sicakl1k $\left({ }^{\circ} \mathrm{C}\right)$} & \multicolumn{2}{|c|}{ Yağ1ş (mm) } & \multirow{2}{*}{$\frac{\operatorname{Nem}(\%)}{2014-2015}$} \\
\hline & & $2014-2015$ & Uzun yillar & $2014-2015$ & Uzun yıllar & \\
\hline \multirow{2}{*}{ Ekim } & Diyarbakir & 17.5 & 17.2 & 34.2 & 33.0 & 60.9 \\
\hline & Mardin & 19.7 & 18.3 & 50.2 & 32.9 & 42.8 \\
\hline \multirow{2}{*}{ Kasim } & Diyarbakır & 8.5 & 9.3 & 97.6 & 52.8 & 70.2 \\
\hline & Mardin & 11.5 & 10.7 & 112.9 & 68.9 & 50.8 \\
\hline \multirow{2}{*}{ Aralık } & Diyarbakır & 6.6 & 3.9 & 73.4 & 71.8 & 87.9 \\
\hline & Mardin & 8.4 & 5.2 & 109.1 & 109.8 & 70.9 \\
\hline \multirow{2}{*}{ Ocak } & Diyarbakır & 2.2 & 1.7 & 64.6 & 69.0 & 80.9 \\
\hline & Mardin & 5.2 & 3.1 & 60.0 & 114.8 & 64.1 \\
\hline \multirow{2}{*}{ Şubat } & Diyarbakır & 5.4 & 3.6 & 55.2 & 67.7 & 80.6 \\
\hline & Mardin & 6.7 & 4.1 & 111.0 & 108.8 & 66.8 \\
\hline \multirow{2}{*}{ Mart } & Diyarbakır & 8.3 & 8.4 & 127.0 & 69.1 & 74.6 \\
\hline & Mardin & 10.1 & 8.0 & 149.9 & 97.6 & 57.9 \\
\hline \multirow{2}{*}{ Nisan } & Diyarbakır & 12.4 & 13.8 & 48.6 & 68.4 & 70.0 \\
\hline & Mardin & 14.5 & 13.5 & 46.3 & 80.5 & 51.0 \\
\hline \multirow{2}{*}{ Mayıs } & Diyarbakır & 18.7 & 19.2 & 48.2 & 44.4 & 58.1 \\
\hline & Mardin & 22.5 & 19.5 & 49.7 & 44.6 & 33.4 \\
\hline \multirow{2}{*}{ Haziran } & Diyarbakır & 26.0 & 26.2 & 7.4 & 8.8 & 36.1 \\
\hline & Mardin & 25.6 & 28.1 & 3.7 & 4.7 & 24.2 \\
\hline $\begin{array}{l}\text { Toplam/ } \\
\text { Ortalama }\end{array}$ & Diyarbakır & 11.7 & 11.5 & 556.2 & 485.0 & 68.8 \\
\hline $\begin{array}{l}\text { Toplam/ } \\
\text { Ortalama }\end{array}$ & Mardin & 14.1 & 12.3 & 692.8 & 662.6 & 51.3 \\
\hline
\end{tabular}

Elde edilen veriler bölünmüş parseller deneme desenine göre varyans analizi MSTAT-C istatistik analiz programı ile yapılmış, ortalamalar arasındaki farklılık LSD çoklu karşılaştırma testi ile kontrol edilmiştir.

\section{Bulgular ve Tartışma}

Farklı lokasyonlarda yetiştirilen tritikale genotiplerine ait verim ve verim unsurlarına ilişkin bulgular Tablo 3'te, incelenen özelliklere ait varyans analiz sonuçları ise Tablo 4'te sunulmuştur.

\subsection{Tane verimi}

Araştırma sonuçlarına göre, tane verimi yönünden, çeşitler ve lokasyonlar arasında istatistiki anlamda $\mathrm{P} \leq 0.01$ düzeyinde önemli farklılıklar tespit edilmiştir (Tablo 4). Tane verimi yönünden tritikale genotiplerinin çalışmada kullanılan buğday çeşitlerine göre daha yüksek verim değerlerine sahip oldukları belirlenmiştir. En yüksek tane verimi $678.5 \mathrm{~kg} \mathrm{da}^{-1}$ ile 41-ITSN-8024 tritikale genotipinde belirlenmiş olup; 41-ITSN8061 ile Cemre ve Pehlivan buğday çeşitleri hariç, incelenen diğer tritikale genotipleri ile aralarındaki farklllık istatistiki olarak önemsiz bulunmuştur. Çalışmada kullanılan çeşit ve hatların ortalama tane verimi değerleri ise 537.5-678.5 $\mathrm{kg} \mathrm{da}{ }^{-1}$ arasında değişim göstermiştir (Tablo 3). Mut ve ark. (2006) Uluslararası Buğday ve Misır
Araştırma Merkezi (CIMMYT)'den elde edilmiş 60 tritikale hattı ile Presto ve Tatlıcak standart tritikale çeşitleri arasında tane verimi ve bazı özellikleri belirlemek amacıyla üç lokasyonda yaptıkları çalışmada, ortalama tane veriminin 358.8-564.4 $\mathrm{kg} \mathrm{da}^{-1}$ arasında değiştiğini; Akgün ve ark. (2007), CIMMYT temin edilmiş 30 hat/çeşit ile yaptıkları çalışmada ise, tritikale hatlarında tane veriminin $229.5-357.1 \mathrm{~kg} \mathrm{da}^{-1}$ arasında değişiklik gösterdiğini bildirmişlerdir.

Diyarbakır lokasyonu ortalaması $499.4 \mathrm{~kg} \mathrm{da}^{-1}$, Mardin ortalamas1 ise $739.1 \mathrm{~kg} \mathrm{da}$ olarak belirlenmiştir. Diyarbakır lokasyonunda düşen yağış miktarı Mardin lokasyonuna göre daha düşük olması tane veriminin düşük olmasının ana nedeni olarak görülmektedir. Mardin lokasyonuna ait yağış dağılımının düzenli olması tane veriminin yüksek olmasına neden olmuştur. Aktaş ve ark. (2009) birim alandan elde edilen tane veriminde; genetik verim potansiyelinin yanı sıra, çevrenin etkisinin de oldukça önemli olduğunu bildirmişlerdir.

\subsection{Bin tane ağırlığı}

Tahillarda, tane kalitesini etkileyen önemli değer olan bin tane ağırlığgi; incelenen çeşit ve hatlarda, 29.89-45.21 g arasında değişim gösterdiği belirlenmiştir. Bin tane ağırlığı en fazla 41-ITSN-8036 (45.21 g) tritikale hattında elde edilirken, en düşük değer 41-ITSN-8061 (29.89 g) 
tritikale hattında elde edilmiştir (Tablo 3). Yapılan varyans analizi sonucunda, hat ve çeşitler arasındaki farklılıklar istatistiki açıdan $\mathrm{P} \leq 0.001$ düzeyinde önemli bulunmuştur (Tablo 4).

Araştırmada bin tane ağırlığı yönünden, lokasyonlar arasındaki farklılıklar ve çeşit $\mathrm{x}$ lokasyon interaksiyonu istatistiki olarak $\mathrm{P} \leq 0.01$ düzeyinde önemli çıkmıştır (Tablo 4). Lokasyon ortalamaları incelendiğinde Mardin ortalaması $36.99 \mathrm{~g}$, Diyarbakır lokasyon ortalaması ise 39.50 g olarak belirlenmiştir (Tablo 3). Lokasyonlar arasındaki farklılık çevre koşulları bin dane ağırlığ 1 üzerine olumlu veya olumsuz yönde etkisi sahip olmasından ileri gelmektedir. Albayrak ve ark. (2006) Samsun koşullarında yaptıkları bir çalışmada, bin tane ağırlığını 33.00-47.18 g; Atak ve Çiftçi (2006) Ankara koşullarında, 32.45-43.62 g ve Çiftçi ve ark. (2010) 43.3-52.5 g olduğunu bildirmişlerdir. Araştırmamızda elde edilen sonuçlar, önceki çalışmalarda elde edilen sonuçlarla benzerlik göstermiştir.

\subsection{Hektolitre ağırlığı}

Hektolitre ağırlığı; tanenin sıkı yapılı ve kabuk yüzeyinin az olması, protein ve un randımanının yüksek olması ile ilişkili bir özelliktir (Atlı, 1999; Sade ve ark., 1999). Çeşit ve hatlara ait hektolitre ağırlıkları 73.13-79.50 kg hL-1 arasında değer almış ve tritikale hatlarında elde edilen hektolitre ağırlığ1 değerleri, buğday çeşitlerine göre daha düşük bulunmuştur. Buna göre çalışmamızda en yüksek hektolitre ağırlığı,79.50 $\mathrm{kg} \mathrm{hL}^{-1}$ ile Pehlivan çeşidinden elde edilmiştir. Bununla birlikte; Pehlivan çeşidinin hektolitre ağırlığı ile 41-ITSN-8023, 41-ITSN-8024, DZ9-01-01, DZ906 hatlar ve Cemre ekmeklik buğday çeşidinin hektolitre ağırlığı arasındaki farklılık istatistiki açıdan önemsiz çıkmıştır (Tablo 3).Yapılan varyans analizi sonucunda, hat ve çeşitler arasındaki bu farklılık istatistiki açıdan $\mathrm{P} \leq 0.001$ düzeyinde önemli bulunmuştur (Tablo 4). Benzer olarak, Abilov (2014) yaptığı bir çalışmada, Pehlivan çeşidinin hektolitre ağırlığının tritikale hatlarından daha yüksek olduğunu bildirmiştir. Bazı tritikale genotiplerinin hektolitre ağırlığının belirlenmesi amacıyla yapılan çalışmalarda; Albayrak ve ark. (2006) 65.95-73.32 $\mathrm{kg} \mathrm{hL}^{-1}$, Mut ve ark. (2006) 65.9-71.1 kg hL ${ }^{-1}$ ve Çiftçi ve ark. (2010) 66.11-72.57 kg hL $\mathrm{kL}^{-1}$ arasında değişim gösterdiğini bildirmişlerdir. Çalışmamızda elde ettiğimiz sonuçlar ile önceki çalışmalar paralellik göstermiştir.

Araştırmada hektolitre ağırlığı yönünden, lokasyonlar arasındaki farklılık istatistiki olarak

Tablo 3. Tritikale hatları ve buğday çeşitlerine ait ortalama verim ve kalite değerleri*

\begin{tabular}{|c|c|c|c|c|c|c|c|}
\hline Genotip & $\begin{array}{l}\text { Tane verimi } \\
\left.(\mathrm{kg} \mathrm{da})^{-1}\right)\end{array}$ & $\begin{array}{l}\text { Bin tane } \\
\text { ağırliğ } 1 \\
\text { (g) }\end{array}$ & $\begin{array}{l}\text { Hektolitre } \\
\text { ağırlığ } \\
\left(\mathrm{kg} \mathrm{hL}^{-1}\right)\end{array}$ & $\begin{array}{l}\text { Protein } \\
\text { içeriği } \\
(\%)\end{array}$ & $\begin{array}{l}\text { Nişasta } \\
\text { içeriği } \\
(\%)\end{array}$ & $\begin{array}{c}\text { Gluten } \\
\text { (Yaş öz) } \\
\text { içeriği } \\
(\%)\end{array}$ & $\begin{array}{c}\text { Zeleny } \\
\text { sedimentasyon } \\
(\mathrm{mL})\end{array}$ \\
\hline 41-ITSN-8022 & $660.2 \mathrm{ab}$ & $41.10 \mathrm{bc}$ & $73.46 \mathrm{~d}$ & $14.94 \mathrm{ab}$ & $62.51 \mathrm{c}$ & 31.90 & 52.40 \\
\hline 41-ITSN-8023 & $586.9 \mathrm{abc}$ & $38.52 \mathrm{~cd}$ & $79.08 \mathrm{ab}$ & $15.24 \mathrm{ab}$ & $62.48 \mathrm{c}$ & 33.78 & 55.36 \\
\hline 41-ITSN-8024 & $678.5 \mathrm{a}$ & $35.05 \mathrm{de}$ & $75.30 \mathrm{a}-\mathrm{d}$ & $15.08 \mathrm{ab}$ & $63.83 \mathrm{abc}$ & 32.71 & 51.63 \\
\hline 41-ITSN-8036 & $659.7 \mathrm{ab}$ & $45.21 \mathrm{a}$ & $73.13 \mathrm{~d}$ & $14.70 \mathrm{ab}$ & $63.51 \mathrm{abc}$ & 32.36 & 51.51 \\
\hline 41-ITSN-8053 & $579.8 \mathrm{abc}$ & $38.03 \mathrm{cde}$ & $73.18 \mathrm{~d}$ & $15.30 \mathrm{ab}$ & $62.46 \mathrm{c}$ & 34.53 & 55.08 \\
\hline 41-ITSN-8061 & $567.7 \mathrm{bc}$ & $29.89 \mathrm{f}$ & $74.47 \mathrm{~cd}$ & $14.55 \mathrm{~b}$ & $62.82 \mathrm{bc}$ & 31.84 & 50.28 \\
\hline Cemre & $537.5 \mathrm{c}$ & $34.49 \mathrm{e}$ & $79.07 \mathrm{ab}$ & $16.19 \mathrm{a}$ & $63.44 \mathrm{abc}$ & 33.56 & 52.78 \\
\hline DZ9-01-01 & $649.5 \mathrm{ab}$ & $39.02 \mathrm{c}$ & $78.29 \mathrm{abc}$ & $14.16 \mathrm{~b}$ & $64.30 \mathrm{a}$ & 31.46 & 48.78 \\
\hline DZ9-01-02 & $669.0 \mathrm{ab}$ & 37.35 cde & $74.90 \mathrm{bcd}$ & $14.00 \mathrm{~b}$ & $64.65 \mathrm{a}$ & 30.53 & 48.67 \\
\hline DZ9-06 & $654.8 \mathrm{ab}$ & $43.84 \mathrm{ab}$ & $78.70 \mathrm{abc}$ & $15.03 \mathrm{ab}$ & $64.17 \mathrm{ab}$ & 33.81 & 51.58 \\
\hline Pehlivan & $568.1 \mathrm{bc}$ & 38.19 cde & $79.50 \mathrm{a}$ & $15.17 \mathrm{ab}$ & $64.12 \mathrm{ab}$ & 33.03 & 52.54 \\
\hline Mardin ortalaması & 739.1 & 36.99 & 71.10 & 15.06 & 62.73 & 36.77 & 56.54 \\
\hline Diyarbakır ortalaması & 499.4 & 39.50 & 81.47 & 14.82 & 64.24 & 28.60 & 47.21 \\
\hline Lokasyon ortalaması & 619.25 & 38.24 & 76.28 & 14.94 & 63.48 & 32.68 & 51.87 \\
\hline LSD \% 5 & 106.8 & 3.967 & 4.452 & 1.504 & 1.377 & 3.677 & 6.981 \\
\hline
\end{tabular}

*: Aynı sütunda aynı harfle gösterilen ortalamalar arasında fark yoktur.

Tablo 4. Araştırmada incelen özelliklere ait varyans analizi (F-değeri) sonuçları

\begin{tabular}{lcccccccc}
\hline $\begin{array}{l}\text { Varyasyon } \\
\text { kaynağ1 }\end{array}$ & S.D. & Tane verimi & $\begin{array}{c}\text { Bin tane } \\
\text { ağırlığ1 }\end{array}$ & $\begin{array}{c}\text { Hektolitre } \\
\text { ağırlığ1 }\end{array}$ & $\begin{array}{c}\text { Protein } \\
\text { içeriği }\end{array}$ & $\begin{array}{c}\text { Nişasta } \\
\text { içeriği }\end{array}$ & $\begin{array}{c}\text { Gluten } \\
\text { (Yaş öz) } \\
\text { içeriği }\end{array}$ & $\begin{array}{c}\text { Zeleny } \\
\text { sedimantasyon }\end{array}$ \\
\hline Lokasyon (L) & 1 & $48.214^{* *}$ & $16.811^{* *}$ & $26.579^{* *}$ & 1.109 & $19.593^{* *}$ & $168.089^{* * *}$ & $112.863^{* * *}$ \\
Çeşit (Ç) & 10 & $3.228^{* *}$ & $16.510^{* * *}$ & $4.961^{* * *}$ & $2.225^{*}$ & $4.819^{* * *}$ & 1.499 & 1.355 \\
Ç x L & 10 & 1.908 & $3.161^{* *}$ & 1.958 & 1.367 & $2.151^{*}$ & 1.597 & $2.193^{*}$ \\
\hline \% V.K. & & 12.97 & 7.80 & 4.39 & 7.57 & 1.63 & 8.46 & 10.12 \\
\hline
\end{tabular}

S.D.: Serbestlik derecesi, ${ }^{*}: \mathrm{P} \leq 0.05,{ }^{* *}: \mathrm{P} \leq 0.01,{ }^{* * *}: \mathrm{P} \leq 0.001$ seviyesinde önemlidir, V.K.: Varyasyon katsayıs 
$\mathrm{P} \leq 0.01$ düzeyinde önemli çıkmıștır (Tablo 4). Lokasyon ortalamaları incelendiğinde Diyarbakır lokasyonu $81.47 \mathrm{~kg} \mathrm{hL}{ }^{-1}$, Mardin lokasyonu $71.10 \mathrm{~kg} \mathrm{hL}^{-1}$ değerlerine sahip olmuştur (Tablo 3). Özer ve ark. (2003) hektolitre ağırlığındaki farklılıkların türe, çeşide ve çevre koşullarına göre değişiklik gösterdiğini bildirmişlerdir.

\subsection{Protein içeriği}

Lokasyon sonuçları incelendiğinde; Diyarbakır lokasyonunda hat ve çeşitlerin ortalama tane protein içeriği \% 14.82, Mardin lokasyonunda ise \% 15.06 olarak belirlenmiştir (Tablo 3). Lokasyonlar arasındaki farklılıklar istatistiki yönden önemli bulunmamıştır (Tablo 4).

Araştırmada kullanılan genotiplerin protein içeriği \% 14.00-16.19 değerleri arasında değişim göstermiştir. Araştırmada en yüksek protein içeriği \% 16.19 ile ekmeklik buğday çeşidi olan Cemre'de elde edilirken, tritikale genotipleri arasında ise en yüksek protein içeriği değeri 41-ITSN-8053 (\% 15.3) hattında elde edilmiştir. Yapılan varyans analizi sonucunda, hat ve çeşitler arasındaki farklılıklar istatistiki açıdan $\mathrm{P} \leq 0.05$ düzeyinde önemli bulunmuştur (Tablo 4). Tahılların protein oranının çevresel koşullar ve genotiplerden etkilendiği bilinmektedir. Erekul ve Köhn (2006) iki lokasyonda dört tritikale çeşidini inceledikleri çalışmalarında, protein içeriğinin \% $10.9-17.0$ aralığında değişim gösterdiğini bildirmişlerdir. On iki (12) tritikale genotipinin incelendiği başka bir çalışmada (Tohver ve ark., 2005) ise, protein içeriğinin $\% \quad 9.7-14.5$ aralığında olduğu belirtilmiştir. Protein içeriği ile ilgili elde ettiğimiz bulgular önceki çalışmalarla benzerlik göstermiştir. Bishnoi ve Hughes (1979) \% 15-16 oranında yüksek protein içeriğine sahip olan tritikale ununun buğday ununa \% 30 civarında ilave edilmesi, ekmeğin besin değerini arttıracağını bildirmiştir.

\subsection{Nişasta içeriği}

Tanenin endosperminde bol miktarda bulunan nişasta bileşeni tohum ağırlığının yaklaşık olarak \% 60’lık kısmını ihtiva etmektedir. Araştırmada kullanılan çeşit ve hatlara ait nişasta içerikleri incelendiğinde, \% 62.46-64.65 aralığında değerler aldığg görülmüştür. En yüksek nişasta içeriğ i değeri \% 64.65 ile DZ9-01-02 hattında elde edilmiştir. DZ9-01-02 tritikale hattından elde edilen bu değer ile 41-ITSN-8024, 41-ITSN-8036, DZ9-01-01, DZ9-06 hatlar ve ekmeklik buğday çeşitlerinin değerleri arasındaki farklılık istatistiki açıdan önemsiz bulunmuştur (Tablo 3).Yapılan varyans analizi sonucunda, hat ve çeşitler arasındaki bu farklılık istatistiki açıdan $\mathrm{P} \leq 0.001$ düzeyinde önemli bulunmuştur (Tablo 4).
Araştırmada nişasta içeriği yönünden, lokasyonlar arasındaki farklılık istatistiki olarak $\mathrm{P} \leq 0.01$ düzeyinde önemli çıkmıştır (Tablo 4). Lokasyon sonuçları kıyaslandığında; Diyarbakır lokasyonunda çeşit ve hatların ortalaması olarak nişasta içeriği \% 64.24, Mardin lokasyonunda ise \% 62.73 olduğu belirlenmiştir (Tablo 3). Tanedeki nişasta miktarları yönünden hatlar ve çevreler arasında önemli farklılıklar görülmüştür. Kızılgeçi ve ark. (2016 a) tanede nişasta birikmesi yüksek nem oranı ile yakın ilişkili olduğunu bildirmişlerdir. Başaklanma döneminde Diyarbakır lokasyonunun Mardin lokasyonuna göre nem oranının yüksek olması nişasta içeriği üzerine etkili olmuştur.

\subsection{Gluten (Yaş öz) içeriği}

Önemli kalite kriterlerinden biri olan gluten içeriği; özellikle hamurun yoğurma, işlenme özellikleri, gaz tutma kapasitesi ve son ürün kalitesi üzerine etkilidir. Araştırmamızda, gluten içeriği \% 30.53-34.53 değerleri aralığında değişim göstermiştir. Çeşitler arasında gluten içeriği yönünden istatistiki açıdan farklılık görülmemesine rağmen (Tablo 4); en yüksek gluten içeriği DZ9-06 (\% 33.81) hattından elde edilmiştir. Diyarbakır lokasyonunda gluten içeriği ortalaması \% 28.60 iken Mardin lokasyonunda \% 36.77 olduğu belirlenmiştir (Tablo 3). Lokasyonlar arasındaki bu farklılık istatistiki açıdan $\mathrm{P} \leq 0.001$ düzeyinde önemli çıkmıştır (Tablo 4). Çalışmamızda gluten içeriği çevre koşullarından önemli derecede etkilenmiştir. Nitekim, bazı araştırmacılar da tanedeki gluten içeriğinin yıllara ve çevre koşullarına göre farklılıklar gösterdiğini rapor etmişlerdir (Atlı, 1999; Martinek ve ark., 2008).

\subsection{Zeleny sedimantasyon}

Zeleny sedimantasyon tanedeki proteinin kalitesi ve miktarını belirlemede kullanılan önemli bir kriterdir. Çalışmamızda elde edilen zeleny sedimantasyon değerleri; hat ve çeşitler bakımından 48.67-52.40 mL arasında değişim göstermiş olup (Tablo 3), araştırmada incelenen çeşitler arasında istatistiki olarak farklılık görülmemiştir (Tablo 4). Lokasyon ortalamalarına göre zeleny sedimantayon değeri Diyarbakır lokasyonunda 47.21 mL iken, Mardin lokasyonunda $56.54 \mathrm{~mL}$ olduğu belirlenmiștir (Tablo 3). Lokasyonlar arasındaki bu farklılık istatistiki açıdan $\mathrm{P} \leq 0.001$ düzeyinde önemli çıkmıştır (Tablo 4). Zeleny sedimantasyon değeri çevre koşullarına göre farklılık göstermiştir. Atlı (1999), sedimentasyon değerindeki farklılı̆̆ın genotiplere bağlı olmasının yanı sıra, iklim faktörününde etkisi olduğunu belirtmektedir. 
Grausgruber ve ark. (2000), zeleny sedimentasyon değerinin kalıtım etkisi altında olduğunu daha çok çeşitten etkilendiğini bildirmişlerdir. Türker (1986), tritikalede yürüttükleri bir çalışmada zeleny sedimantasyon değerinin $24.7 \mathrm{~mL}$ olduğunu bildirmiştir. Kızılgeçi ve ark. (2016b) makarnalık buğdayda yaptıkları çalışmada, zeleny sedimantasyon değerinin 49.72- $65.21 \mathrm{~mL}$ arasında değiştiğini bildirmişlerdir.

\section{Sonuçlar}

Marjinal ve fakir tarım alanlarında daha yüksek verim almak amacıyla geliştirilen tritikalenin üretimi, dünya genelinde istenilen seviyeye ulaşmaması ve beklenen ilgiyi görmemesi nedeniyle Uluslararası Buğday ve Mısır Araştırma Merkezi (CIMMTY), tritikale geliştirme islah programını kapatmıştır. Çalışmada elde edilen sonuçlar incelendiğinde; bazı tritikale genotiplerinin ekmeklik buğdaya kıyasla yüksek tane verimine ve benzer kalite değerlerine sahip olması, hatta, bazı kalite özellikleri yönünden ekmeklik buğdayı geçmesi bu bitkinin iyi değerlendirilmediğini göstermektedir. Özellikle ekonomik analizlerininde yer aldığı daha geniş kapsamlı tritikale denemelerinin yürütülmesi ve çiftçiler tarafında tarımının yapılmasına ihtiyaç olduğu görülmektedir. Diyarbakır ve Mardin koşullarında verim ve kalite özellikleri yönüyle incelenen tritikale hatlarından elde edilen sonuçlara göre; Dicle Üniversitesi Ziraat Fakültesi tarafından geliştirilen DZ9-06 tritikale hattının hem verim ve hem de kalite yönünden yüksek değerlere sahip olmasından dolayı, bu hattın çeşit adayı olarak değerlendirilebileceği sonucuna varılmıştır.

\section{Kaynaklar}

Abilov, R., 2014. Farklı tritikale hatlarının verim ve verim öğelerinin belirlenmesi. Yüksek lisans tezi, Uludağ Üniversitesi Fen Bilimleri Enstitüsü, Bursa.

Akgün, İ., Kaya, M., Altındal, D., 2007. Isparta ekolojik koşullarında bazı tritikale hat/çeşitlerinin verim ve verim unsurlarının belirlenmesi. Akdeniz Üniversitesi Ziraat Fakültesi Dergisi, 20(2): 171182.

Aktaş, B., Aydemir, T., Yılmaz, K., İkincikarakaya, S., 2009.Bazı tritikale (X Triticosecale Witt.) genotiplerinin kuru koşullarda tane verimi stabilitesi. Tarla Bitkileri Merkez Araştırma Enstitüsü Dergisi, 18(1-2): 30-35.

Albayrak, S., Mut, Z., Töngel, Ö., 2006. Tritikale ( $X$ Triticosecale Wittmack) hatlarında kuru ot ve tohum verimi ile bazı tarımsal özellikler. Süleyman Demirel Üniversitesi Ziraat Fakültesi Dergisi, 1(1): 13-21.

Anonim, 2016. Bitkisel Üretim İstatistikleri, www.tuik.gov.tr (Erişim Tarihi: 17.07.2016).
Atak, M., Çiftçi, C.V., 2006. Bazı tritikale çeşit ve hatlarının morfolojik karakterizasyonu. Tarım Bilimleri Dergisi, 12(1): 101-111.

Atlı, A., 1999. Buğday ve ürünleri kalitesi. Hububat Seтроzуоти, Bildiri Kitabı, 8-11 Haziran, Konya, s. 498-506.

Bağc1, S.A., Ekiz, H., 1993. Tritikalenin insan ve hayvan beslenmesindeki yeri. Konya'da Hububat Tarımının Sorunları ve Çözüm Yolları Sempozyumu, Bildiri Kitab1, 12-14 May1s, Konya, s. 12-14.

Bishnoi, U.R., Hughes, J.L., 1979. Agronomic performance and protein content of fall planted triticale, wheat and rye. Agronomy Journal, 71(2): 359-360.

Çiftçi, A.E., Kınabaş, S., Yelbey, S., Yağdı, K., 2010. Bazı tritikale hatlarının kalite özellikleri ve ekmek yapımında kullanılma olanaklarının araştırılması. Uludă̆ Üniversitesi Ziraat Fakültesi Dergisi, 24(2): 93-102.

Erekul, O., Köhn, W., 2006. Effect of weather and soil conditions on yield components and bread making quality of winter wheat (Triticum aestivum L.) and winter triticale (Triticosecale Wittm.) varieties in north-east Germany. Journal of Agronomy and Crop Science, 192(6): 452-464.

Genç, İ., Yağbasanlar, T., Ülger, A.C., Kırtok, Y., 1987. Çukurova koşullarında tritikale'nin verim ve verim öğeleri üzerinde bir araştırma. Türkiye Tahıl Sетроzуити, Bildiri Kitab1, 6-9 Ekim, Bursa, s. 6-9.

Grausgruber, H., Oberforster, M., Werteber, M., Ruckenbauer, P., Volmann, J., 2000. Stability of quality traits in austrian-grown winter wheats. Field Crops Research, 66(3): 257-267.

Kızılgeçi, F., Yıldırım, M., Akıncı, C., Albayrak, Ö., 2016a. Bazı arpa genotiplerinin Diyarbakır ve Mardin koşullarında verim ve kalite parametrelerinin incelenmesi. I $\breve{g} d ı r$ University Journal of the Institute Science and Technology, 6(3): 161-169.

Kızılgeçi, F., Yıldırım, M., Albayrak, Ö., Başdemir, F., Akıncı, C., 2016b. Farklı azot dozlarının makarnalık buğday F2 melez kombinasyonlarında bazı kalite parametreleri üzerine etkisi. Dicle Üniversitesi Fen Bilimleri Enstitüsü Dergisi, 5(1): 7-14.

Martinek, P., Vinterova, M.,Buresova, I., Vyhnanek, T., 2008.Agronomic and quality characteristics of triticale ( $X$ Triticosecale Wittmack) with HMW glutenin subunits 5+10. Journal of Cereal Science, 47(1): 68-78.

Mut, Z., Albayrak, S., Töngel, Ö., 2006. Tritikale (X Triticosecale Wittmack) hatlarının tane verimi ve bazı özelliklerinin belirlenmesi. Ankara Üniversitesi Ziraat Fakültesi Tarım Bilimleri Dergisi, 12(1): 5664.

Osborne, B.G., 2006. Applications of near infrared spectroscopy in quality screening of early-generation material in cereal breeding programmes. Journal of Near Infrared Spectroscopy, 14(2): 93-101.

Özer, M.S., Özkan, H., Kola, O., Kaya, C., 2003. Ç.Ü.Z.F. tarla bitkileri bölümü tarafından yetiştirilen bazı ekmeklik buğday ve tritikale çeşit ve hatları ile bölgemiz çiftliklerinde üretilen ticari buğday 
çeşitlerinin fiziksel, kimyasal ve teknolojik özelliklerinin belirlenmesi. Glda, 28(3): 251-257.

Sade, B., Topal, A., Soylu, S., 1999. Konya sulu koşullarında yetiştirilebilecek makarnalık buğday çeşitlerinin belirlenmesi. Orta Anadolu'da Hububat Tarımının Sorunları ve Çözüm Yolları Sempozyumu, Bildiri Kitabı, 8-11 Haziran, Konya, s. 91-96.

Tohver, M., Kann, A., That, R., Mihhalevski, A., Hakman, J., 2005. Quality of triticale cultivars suitable for growing and bread-making in northern conditions. Food Chemistry, 89(1): 125-132.
Türker, S., 1986. Bazı tritikale cesitlerinin kimi teknolojik özellikleri üzerinde araştırmalar. Yüksek lisans tezi, Selçuk Üniversitesi Fen Bilimleri Enstitüsü, Konya.

Yağbasanlar, T., 1987. Çukurova'nın taban ve kıraç koşullarında farklı ekim tarihlerinde yetiştirilen değişik kökenli yedi triticale başlıca tarımsal ve kalite özellikleri üzerinde araștırmalar. Doktora tezi, Çukurova Üniversitesi Fen Bilimleri Enstitüsü, Adana. 